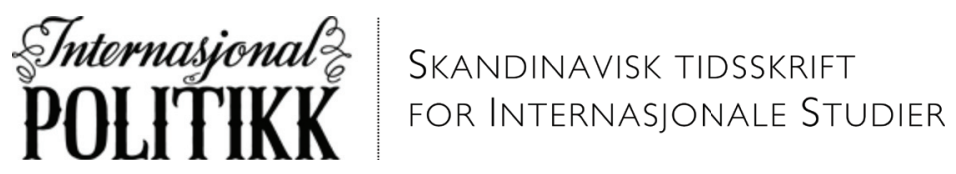

Årgang 75, Nummer 3/4, side 203-211, 2017, ISSN 1891-5580, www.tidsskriftet-ip.no, Publisert mars 2018

\author{
Fokus: Diplomatiminister BRende
}

\title{
Diplomatiminister Brende
}

\author{
Halvard Leira \& Nina Græger \\ NUPI
}

Den 20. oktober 2017 fratrådte Børge Brende som norsk utenriksminister, etter litt over fire år i embedet. I nyere norsk historie er dette en ganske lang periode, etter 1973 er det bare Knut Frydenlund, Svenn Stray, Thorvald Stoltenberg og Jonas Gahr Støre som har sittet lengre som utenriksministre. Men fikk han også til mye? Ved skifte av minister i Solberg II-regjeringen, synes det rimelig å gjøre opp regnskap.

I tidligere omganger har forskermiljøet ved NUPI diskutert og vurdert ulike sider ved og aktører i norsk utenrikspolitikk. Vi har analysert utenriksministre fra Vårvik til Støre (Græger 2010; Neumann 2010; Leira 2013), utenrikspolitisk praksis i ulike sektorer og institusjoner (Kjos-Fonn, Neumann \& Sending 2006), stortingsmeldinger om norsk utenrikspolitikk (Græger 2009), de lange linjer (Neumann \& Leira 2005, Leira 2005; Knutsen et al. 2016) samt deltatt i konkrete prosesser, som Refleks \& Veivalg (f.eks. Græger 2007; Holm og Weltzien 2017; Holm i denne fokusspalten).

Vurderingen av Brendes innsats og resultater som utenriksminister må nødvendigvis bli foreløpig. Selv om noen resultater er umiddelbare og konkrete, tar det ofte tid før de fulle konsekvensene av politikk eller fravær av politikk blir tydelige. Konsekvensene av UDs manglende kriseberedskap da tsunamien rammet i 2004 var på den ene side umiddelbart klare, og førte ganske raskt til en ny kriseberedskapsstruktur og -kultur i departementet (se Leira 2017; Græger \& Lindgren 2017). De positive effektene av Torvald Stoltenbergs åpning for fredsdiplomati på begynnelsen av 1990-tallet fortsetter på den annen side å gjøre seg gjeldende 25 år etter at initiativene ble igangsatt, samtidig som denne politikken i perioder har vært vanskelig å forene med Norges økte militære engasjement i utenlandsoperasjoner, og særlig i krigen mot 
terror. Med dette forbeholdet om politikkens iboende treghet er det likevel rimelig å spørre, hva sitter vi igjen med etter fire år med Brende?

Uten å foregripe resten av fokusspalten for mye, er det tentative svaret «ganske lite». Blant de lengstsittende utenriksministrene i nyere tid giorde Stoltenberg kreative grep for å sikre Norge en ny rolle i en omskiftelig verden, der de nye borgerkrigene og intra-statlige konfliktene etter den kalde krigen skapte behov for både fredsmekling og bidrag til fredsoperasjoner. Støre dreide fokus mot nordområdene og gjorde en betydelig innsats for å endre det norske utenrikspolitiske ordskiftet. Dette var proaktive utenrikspolitiske grep, rettet mot Norges totale interaksjon med omverden og som hevet Norges status som utenrikspolitisk aktør internasjonalt, men også bekreftet og befestet nasjonale selvbilder (de Carvalho \& Neumann 2015, Leira 2007). Børge Brende har i mye større grad fremstått som en snevrere, mer reaktiv "diplomatiminister" som har fokusert på konkrete politiske og personlige relasjoner. Med 'diplomatiminister' mener vi en minister som primært har utadrettet fokus, og som er mer opptatt av relasjonsbygging og tilstedeværelse ute, enn politisk forankring hjemme (se også nedenfor). I dette legger vi ingen negativ vurdering av diplomati, snarere tvert imot. Diplomatiet, forstått som en institusjon som er profesjonelt innrettet mot å håndtere (og forlike) forskjell, har en åpenbar og viktig systemopprettholdende og konfliktdempende funksjon. Verden trenger mer, snarere enn mindre diplomati. Det har også blitt foreslått at Norge i det 21. århundre kunne satse på å utvikle mellommanns- eller meklerrollen (det vil si diplomatiet) som sitt internasjonale komparative fortrinn. Men det er ikke gitt at denne rollen bør fylles av ministeren som har ansvar for utenriksdepartementet, hun må nødvendigvis også ha forankring hjemme. Et diplomati som er løsrevet fra den hjemlige politiske debatten, er et diplomati som er svakere enn det burde ha vært, og som er sårbart for innenrikspolitiske svingninger.

En overordnet prioritering av diplomati lå i noen grad i kortene allerede da regjeringen Solberg tiltrådte. Brende mistet Europaporteføljen, en viktig politikkarena i utenrikspolitikken og en av Høyres hjertesaker, til en egen minister. Utenriksministerens rang i regjeringen ble også nedjustert. ${ }^{1}$ Samtidig ble imidlertid utviklingsministerposten fjernet, slik at Brende i prinsipp kunne integrere denne delen av utenrikspolitikken, som har de langt største budsjettpostene, tettere med resten av feltet. Dette skjedde i liten grad.

Diplomatiministeren viste seg også i praksis. Brende hadde lang politisk fartstid bak seg fra Stortinget, der han var innvalgt i tre perioder (møtte bare 1997-2001), og som miljøvernminister (2001-2004) og næringsminister (2004-2005), før han ble utnevnt til utenriksminister i 2013. Brende kom tilbake til norsk politikk fra en

${ }^{1}$ Tradisjonelt rangerte utenriksministeren etter statsministeren, og ev. lederne for andre koalisjonspartier. Med regjeringen Solberg ble dette endret til en kombinasjon av individuelt fastsatt rang og ansiennitet, jf. https://www.regjeringen.no/no/dokumenter/om-statsrad/id593521/sec1 (301017). 
stilling som administrerende direktør i World Economic Forum i Genève, og returnerte til organisasjonen som president da han, som den første utenriksminister siden Stoltenberg, og den første borgerlige utenriksminister siden John Lyng, gikk av etter eget ønske. Internasjonal interaksjon med andre ledere tok diplomatiministeren med seg som modus operandi fra jobben i Genève. Med rundt 200 reisedøgn i året (de fleste utenfor Norge), var han mye oftere borte fra Norge enn det forgjengerne hadde vært. Helt eksakte tall finnes ikke, men Brende hadde om lag 250 reisedøgn på sine første 14 måneder som minister, og om lag 180 i hele 2016. Til sammenligning hadde Støre på sine siste 21 måneder som utenriksminister, 187 reisedøgn. ${ }^{2}$

Vårt argument over de neste sidene er at Brende ikke bare var borte fra Norge, men også i stor grad var borte fra utenrikspolitikken. Men var denne abdikasjonen en funksjon av internasjonale og norske utviklingstrekk, eller av måten disse ble håndtert på? I resten av denne innledningen ser vi først kort på de sentrale eksterne og interne handlingsbetingelsene, og hvordan de skapte muligheter for og la begrensninger på Brendes handlingsrom. Vi bruker her sikkerhetspolitikken som empirisk eksempel. Videre diskuterer vi hvordan han møtte disse mulighetene og begrensningene, med fokus på håndteringen av den hjemlige debatten om utenrikspolitikk. Til slutt presenterer vi noen muligheter og utfordringer ved det å være diplomatiminister, og gir et kort riss av spaltens øvrige bidrag.

\section{Utenrikspolitisk handlingsrom 2013-I7}

Den tradisjonelle forståelsen av utenriksdepartementer, har vært at de har en slags portvokterrolle, de vokter og håndterer grenseflatene mellom staten og andre stater. Denne forståelsen er i dag upresis. Inspirert av Henry Kissinger og Ole Wæver, kan man i stedet forstå utenriksministere som en form for meglere, som forsøker å få statens innside og utside til å gå ihop. I et land som Norge, bør UD i starten av det 21. århundre forstås som en node $i$ et nettverk som binder sammen mange aktører innenfor og utenfor landets grenser (Leira \& Sverdrup 2013; Leira \& Sverdrup 2015). En utenriksminister skaper seg dermed best mulig handlingsrom ved å innta posisjoner "i margen av flest mulig institusjoner" (Neumann 2010: 118), der institusjonene forstås som konkretiseringer av eksterne og interne strukturer. En utenriksminister som for eksempel har godt samarbeid med nære allierte, formelle og uformelle posisjoner $\mathrm{i}$ internasjonale fora, vennlig relasjon med pressen og sterk posisjon i eget parti, vil $i$ en relativt stabil verden være en utenriksminister med stort handlingsrom. Intern og ekstern ustabilitet kan både øke og innskrenke handlingsrommet, det kan giøre verden mer uoversiktlig, men også skape nye muligheter.

${ }^{2}$ https://www.nrk.no/norge/brende-er-reisemesteren-1.12078568 (301017), https://www. aftenposten.no/verden/i/egrQg/Utenrikspolitikken-blir-til-mens-han-reiser NRK Urix (12/10 2017) oppga ved Brendes avgang at han hadde 432 reisedøgn på 4 år, men det er vanskelig å få det tallet til å gå opp med tallene referert i sakene over. 
Eksternt var fireåresperioden 2013-2017 preget av økende ustabilitet. Russlands anneksjon av Krim og destabilisering av Ukraina, og de påfølgende sanksjonene, skapte nye spenninger i forholdet mellom Vesten og Russland. Brexit og oppslutningen om populistiske partier ledet til uro om Europas og EUs videre kurs (Haugevik 2017). Valget av Donald Trump til amerikansk president skapte usikkerhet om sikkerhetsgarantien og USAs engasjement i NATO (Romarheim 2017). Etterdønningene etter den arabiske våren og særlig borgerkrigen i Syria, sammen med borgerkrig iYemen og en rekke humanitære katastrofer skapte problemer lokalt og var med på å utløse en flyktningkrise for Europa. Brende arvet også et vanskelig forhold til Kina fra sine forgjengere (Sverdrup-Thygeson 2016).

Utenriksminister Brendes svar på de endrede sikkerhetspolitiske rammebetingelsene, Veivalgsmeldingen (Meld. St.36, 2016-2017), som kom helt på tampen i hans periode, vektla like fullt en videreføring av norsk utenriks- og sikkerhetspolitikk, herunder: å bevare de transatlantiske båndene og videreutvikle det sikkerhetspolitiske samarbeidet med USA; bidra til omstilling i NATO for å styrke kollektivt forsvar; styrke norsk forsvarsevne; samt videreutvikle samarbeidet med Russland. Det eneste nye - men som i praksis hadde pågått i noen år i forsvarspolitikken - var en forsiktig opptrapping av det sikkerhetspolitiske samarbeidet med utvalgte europeiske og de nordiske land, en styrking av bidraget til europeisk sivil og militær krisehåndteringsevne (herunder antiradikaliserings- og integreringstiltak), samt å arbeide for å bedre NATO-EU samarbeidet. Disse tiltakene var ikke nok for å styrke Brendes sikkerhetspolitiske credo, samtidig som forslaget om økt innsats overfor sårbare stater i Europas ustabile nabolag ikke greide å stille kritikken fra dem som ønsket større oppmerksomhet om den bredere sikkerhetspolitiske agendaen.

I tillegg manglet meldingen også et overordnet grep for å forstå og svare på den sikkerhetspolitiske usikkerheten. Kontrasten til Stortingsmelding nr. 15 fra 2009, den første helhetlige gjennomgangen av norsk utenrikspolitikk etter den kalde krigens slutt, er slående. Den (re)introduserte interessebegrepet som fundamentet i norsk utenrikspolitikk ut fra tanken om at 'globaliseringen reduserer avstanden mellom idealer og «realiteter»' (Græger 2009: 517). Engasjementspolitikken, områder der Norge kunne 'gjøre en forskjell', ble derfor nyttig i realpolitisk forstand, samtidig som militære maktmidler kunne brukes idealpolitisk (Utenriksdepartementet 2008-09: 20). I stort representerte Stortingsmelding nr. 36 altså en videreføring og -utvikling og styrking av eksisterende sikkerhetspolitikk; den foretok ingen veivalg.

Som Brende selv oppsummerte i et intervju med VG på sin siste dag som utenriksminister: '-I en veldig urolig verden har vi klart å holde bred enighet om utenriks og sikkerhetspolitikk i Norge. Og vi har klart å håndtere de løpende sakene i vår interesse.' ${ }^{3}$ Denne utpregede 'business as usual'-linjen, med fokus på løpende saksbehandling, har ofte preget norsk utenriks- og sikkerhetspolitikk. En vanlig kritikk av denne linjen, som for eksempel rammet Jan Petersen, er at den fører til manglende

${ }^{3}$ https://www.vg.no/nyheter/utenriks/boerge-brende/i-dag-gaar-boerge-brende-avsom-utenriksminister-tror-ikke-russland-angriper-et-naboland-igjen/a/24167263/ 
overblikk og forståelse for de bredere utviklingstrekkene. Det klare fokuset på enighet og reaktivitet innebar at Brende fremsto som nokså uinteressert og uengasjert i norsk sikkerhetspolitikk i perioden 2013-17.

Siden midten av 1990-tallet har Forsvaret vært et instrument både for utenrikspolitikken og sikkerhetspolitikken (Græger 2016). I periodene før Brende, sikret globale maktskifter, den endrede geostrategiske situasjonen i nordområdene, og det norske Afghanistan-engasjementet utenriksministrene Støre og Eide et godt inntak til sikkerhetspolitikken. Men krigen mot terror, Russlands 'foroverlente' utenrikspolitikk og NATOs fokus på kollektivt forsvar etter 2008 (Georgia) og særlig etter 2014 (Ukraina), ga naturligvis forsvarsministeren stort spillerom. Det kjølige, og etterhvert dypfryste klimaet mellom USA og Russland skulle i utgangspunktet gi en diplomatiminister som er dyktig i relasjonsbygging stort spillerom. Det skjedde ikke. Under Brende har Forsvarsdepartementet (FD) og forsvarsministeren, også fra Høyre, dominert den hjemlige debattarenaen og mediene ikke bare i forsvarspolitikken, men også i sikkerhetspolitikken. Totalt sett har derfor UDs funksjonstap til FD i sikkerhetspolitikken, som startet for mer enn ti år siden (Græger \& Neumann 2006; Græger 2010), i stor grad preget Brendes periode. Gitt at hans etterfølger, Ine Marie Eriksen Søreide, kommer til utenriksdepartementet fra stillingen som forsvarsminister (2013-17), kan vi de neste årene få en praktisk test på om initiativet $\mathrm{i}$ sikkerhetspolitikken avhenger av person, eller om det nå er så festet $\mathrm{i}$ institusjoner at UD må finne seg $\mathrm{i}$ å spille annen fiolin på dette feltet.

Internt satt Brende $\mathrm{i}$ en mindretallsregjering, som allikevel hadde en relativt stabil flertallskoalisjon bak seg. Og regjeringspartnerens skepsis mot norsk engasjementspolitikk ble på forutsigbart vis balansert av støttepartienes insistering på å videreføre en norsk linje, der noen endringer i innretningen av engasjementet kan godtas, så lenge hovedlinjene videreføres (Leira 2012). I sum hadde Brende et eksternt handlingsrom i betydelig fluks - med både utfordringer og muligheter, og et relativt stabilt internt handlingsrom. Hvis han ønsket å gjøre større grep i ført utenrikspolitikk, eller å utfordre den hjemlige tenkningen omkring utenrikspolitikk, så hadde han i prinsippet betydelige muligheter til det.

\section{Diplomatiminister med medieutfordringer}

Vår påstand $\mathrm{i}$ dette og de andre bidragene til denne spalten, er altså at det utenrikspolitiske handlingsrommet ble dårlig utnyttet, og at Brende tvert imot viste liten interesse for både å føre politikk og å ta grep hjemme. Symptomatisk for denne tilnærmingen til det utenrikspolitiske feltet, var hans manglende engasjement med norsk presse, politikk og sivilsamfunn. En konsekvens av å være omreisende diplomatiminister er nødvendigvis at det blir mindre tid til å pleie kontakter på hjemmebane.

I utgangspunktet er det å være norsk utenriksminister en takknemlig posisjon. De hjemlige interessegruppene som virkelig bryr seg om utenrikspolitikk er stort sett statsfinansierte NGOer, og selv om velgerne sier at de er opptatt utenrikspolitikk, så avgjør den 
uhyre sjelden valg (Narud et al. 2010). Med noen få unntak nær scorer utenriksministeren jevnlig helt på topp $\mathrm{i}$ avisenes popularitetsmålinger for regjeringsmedlemmer. Dette var også tilfelle for Brende, som var jevnt over den mest populære statsråden i regjeringen Solberg. Men hans gjennomsnittlige popularitet var betydelig lavere enn den Støre opplevde som utenriksminister. ${ }^{4}$ En nærliggende tolking er at enhver utenriksminister som unngår skandaler og katastrofer, vil være relativt populær sammenlignet med sine regjeringskollegaer, som møter kontinuerlig kritikk på hjemmebane. Men for å bli genuint populær, må en utenriksminister ha noe mer å by på, og hun bør ha media på sin side. Som Støre fikk oppleve, kan norske media være ekstremt servile overfor utenriksministre, og tillate at de får dosere nærmest fritt (Eggen et al. 2015).

For å oppnå velvilje fra media, så må ministrene være tilgjengelige. Fournalisten har to ganger de siste årene sett på hvor ofte forskjellige politikere stiller i Dagsnytt Atten. I løpet av de elleve første månedene av 2014 var Brende den politikeren som oftest deltok, hele 28 ganger. ${ }^{5}$ Men dette var allikevel langt bak Støre, som de første elleve månedene av 2011 deltok 41 ganger. ${ }^{6}$ Den klare trenden utover i regjeringsperioden var at Brende gjorde seg mindre tilgjengelig for media, og også var mindre opptatt av å stille i utenrikspolitiske debatter mer generelt. I valgkampen 2017 stilte han knapt opp i debatter i det hele tatt. Med mindre tilgjengelighet følger ofte mindre velvilje. Dagsavisen, som i utgangspunktet var nøytralt innstilt til Brende, reiste for eksempel allerede sommeren 2015 spørsmålet "hva har Brende gjort den siste tida foruten å gå opp og ned flytrapper med en koffert full av penger?". ${ }^{7}$ Klarest kom medias skepsis til syne i Brendes avskjedsintervju i NRK Urix, der ministeren opplevde såpass kritiske spørsmål at hans politiske rådgiver tok til motmæle dagen etterpå for å korrigere bildet og fortelle om alt det gode Brende hadde fătt til. ${ }^{8}$ Det synes nærliggende å se den kritiske tonen i lys av det media opplevde som en vanskelig tilgjengelig minister - avskjedsintervjuet ble anledningen til å stille spørsmål som media hadde villet reise lenge.

\section{Utfordringer på 'hjemmebane': Storting og departement}

En minister som har problemer med media, kan allikevel sikre seg ryggdekning ved støtte i departement, Storting og parti. Allerede ganske tidlig i regjeringsperioden kom det imidlertid mishagsytringer. På Stortinget ble det notert at ministeren sjelden møtte opp for å redegjøre og svare på spørsmål, og til pressen ble det lekket at Brende

${ }^{4}$ Fra han tiltrådte høsten 2005 til desember 2008, svarte for eksempel i snitt over $57 \%$ av de spurte iVG/InFacts målinger at de hadde svært stor eller stor tillit til Støre (VG $26 / 12$ 2008). Brende scoret over $60 \%$ da han tiltrådte, men stabiliserte seg deretter på mellom 45 og 50\% (VG 15/10 2014, 15/12 2015, 12/2 2016). ${ }^{5}$ https://journalisten.no/2014/11/kongene-av-dagsnytt-18 (041117). ${ }^{6} \mathrm{https} / / /$ journalisten.no/2011/12/gahr-store-pa-topp (041117).

${ }^{7}$ Dagsavisen 24/6 2015.

${ }^{8} \mathrm{https} / / / w w w . n r k . n o / y t r i n g / u r i x-b o m m e r-1.13732296$ (051117). 
“vekker [...] ikke samme begeistring som før i partiet”. ${ }^{9}$ Internt i UD ble det kommentert at man hadde en minister som nesten alltid var på reise, men som allikevel var uvillig til å delegere, og drev utstrakt detaljstyring. ${ }^{10}$ I et departement fullt av høyt utdannet og høyt kompetent arbeidskraft måtte en slik lederstil nødvendigvis virke demoraliserende. På toppen av dette kom uklare bestillinger til embedsverket, med korte frister og manglende tilbakemeldinger, og høyt arbeidspress over lang tid, som konkretisert $\mathrm{i}$ en intern bekymringsmelding våren 2015. ${ }^{11}$ Som Dagsavisen syrlig oppsummerte "Vi kan ikke kreve at utenriksministeren skal skape fred på jord, men han må klare skape fred innad i Utenriksdepartementet". ${ }^{12}$

Inntrykket av en diplomatiminister med noe manglende forankring hjemme var tydelig i hva Brende selv trakk frem som det kanskje viktigste resultatet i hans periode, gjenopprettingen av regulær politisk kontakt med Kina: 'Om jeg skal nevne en enkeltsak, har vi fått på plass et normalisert forhold til Kina.' ${ }^{13}$ Selv om den var forankret i en utenrikspolitisk prioritering, var dette en typisk bilateral diplomatisk sak. Som Brende selv kommenterte i NRK Urix, var det en sak med "diplomatisk arbeid som var veldig møysommelig”. ${ }^{14}$ Det er åpenbart at det lå godt diplomatisk håndverk til grunn for avtalen fra Brende selv og hans departement, men selv om mange i Norge hilste den velkommen, så regnes den ikke unisont som noen gevinst. Menneskerettsaktivister, politikere, forskere og journalister har vært mer eller mindre skeptiske, som Dagbladet oppsummerte denne delen av Brendes virke: "Har normalisert forholdet til Kina, men til hvilken pris?". ${ }^{15}$

Det er ikke gitt at en utenriksminister med sterkere tilknytning til det norske hjemmemiljøet ville ha unngått kritikk for avtalen med Kina, men det er rimelig å anta at et sterkere og tydeligere forarbeid på hjemmebane, kunne ha dempet kritikken. For Brende var den hjemlige forankringen imidlertid nedprioritert.

\section{Diplomatiministeres muligheter og utfordringer i en ny tid}

Mange utenriksministere, i mange land, har først og fremst vært diplomatiministere. Historisk sett var det gjerne diplomater som ble utenriksministre, og det å kunne pleie

${ }^{9}$ Stavanger Aftenblad 29/12 2014.

${ }^{10} \mathrm{https}: /$ www.dagbladet.no/kultur/borge-brente-ut/68795611 (051117), https://www. nrk.no/urix/_-borge-brende-har-vaert-en-svaert-svak-utenriksminister-1.13690868 (051117).

${ }^{11}$ https://www.vg.no/nyheter/innenriks/i/E7oz5/vg-avslorer-utenriksminister-borgebrende-far-sterk-kritikk-i-ud/. Se også Neumann (2017) i denne spalten.

${ }^{12}$ Dagsavisen 16/12 2015.

${ }^{13}$ https://www.vg.no/nyheter/utenriks/boerge-brende/i-dag-gaar-boerge-brende-avsom-utenriksminister-tror-ikke-russland-angriper-et-naboland-igjen/a/24167263/

${ }^{14}$ https://tv.nrk.no/serie/urix/nnfa53101217/12-10-2017 (051117).

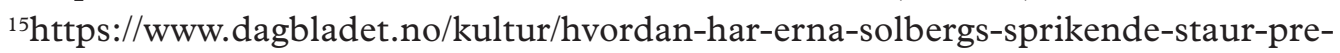
stert-i-aret-som-er-gatt/67727329 (051117). 
andre lands diplomater kunne være vel så viktig som å stake ut en bestemt politisk kurs. Med jetfly og stadig hyppigere konferansediplomati, har en ny form for diplomatiministere steget frem, hvileløst pendlende mellom konfliktområder, hovedsteder og konferansehoteller. Ettersom alle departementer i et land som Norge nå fører politikk overfor omverden, gir det en slags mening at utenriksdepartementene i noen grad spesialiserer seg nettopp på diplomatisk samkvem, og at utenriksministeren blir mer av en diplomatiminister. Særlig tydelig er denne tendensen i land der mer av den utenrikspolitiske koordineringen legges til president eller statsminister (jf. Udgaard 2006).

For utenriksministeren følger det imidlertid noen utfordringer med først og fremst å være diplomatiminister. Den hjemlige forankringen, som for mange utenriksministre allerede er svak på grunn av velgernes begrensede interesse for feltet, $\mathrm{i}$ hvert fall i fredelige tider, kan forvitre nesten fullstendig ved utstrakt globe-trotting. Og der utenriksministere inntil for få år siden kunne regne med å få innta ekspertrollen i nasjonale media, bidrar de pågående endringene i medielandskapet til at det er mye vanskeligere å få etablert en enhetlig ekspertrolle. Halvard Lange kunne kalle inn de sentrale redaktørene til møte i UD, og regne med å styre samtalen om norsk utenrikspolitikk. Jonas Gahr Støre forsøkte, og lyktes ganske godt, med å oppnå det samme gjennom utrettelig konsensusbygging nedenfra og opp og ved å konsekvent stille opp for media. Espen Barth Eide hadde også stor troverdighet og behersket ekspertrollen. Det kan synes som om Børge Brende antok at rollen fulgte med jobben, og han gjorde lite for å opparbeide seg en selvstendig ekspertrolle. Han reagerte også tydelig negativt når han møtte kritikk, noe som er litt overraskende gitt hans lange politiske erfaring. I dette analytiske perspektivet er spørsmålet om kritikken var berettiget eller ikke underordnet, det springende punktet er at Brende hadde posisjonert seg slik at han dels ikke evnet å se kritikken komme, dels ikke kunne aksepterte den når den kom. De betydelige diplomatiske gjennombruddene som Brende sto for, ble dermed i noen grad overskygget av hans manglende grep om politikken.

I de resterende bidragene til denne spalten går vi først dypere inn i Brendes manglende engasjement med utenrikspolitikken, deretter vurderer vi diplomatiministerens diplomati. Minda Holm sammenligner Brendes utredningsprosjekt "Veivalg" med Jonas Gahr Støres Refleks-prosjekt, Kristin M. Haugevik og Nina Græger tar opp europapolitikkens rolle under en diplomatiminister uten EU-portefølje, Jon-Harald Sande Lie vurderer hvordan FN-arbeidet og bistanden har utviklet seg med en omreisende minister mens Benjamin de Carvalho og Morten S. Andersen går inn på suksesshistoriene Colombia og Kina. Endelig avrunder Iver B. Neumann med en samlet vurdering av Brendes periode.

\section{Om forfatterne}

Halvard Leira er seniorforsker på NUPI og tidligere redaktør av Internasjonal Politikk. Han har publisert bredt om diplomati, utenrikspolitikk, internasjonal politisk tenkning og historisk internasjonal politikk, for eksempel i Review of International Studies, Millennium, Leiden Fournal of International Law, International Studies Perspectives, The Hague 
Fournal of Diplomacy, Global Society og Cooperation and Conflict. Seneste bok på norsk (med Torbjørn L. Knutsen og Iver B. Neumann): Norsk Utenrikspolitisk Idehistorie 1890-1940. (Oslo: Universitetsforlaget, 2016).

Nina Græger er seniorforsker ved NUPI og har publisert bredt om norsk og europeisk utenriks-, sikkerhets- og forsvarspolitikk. Hennes siste bok på norsk er Norsk forsvarspolitikk. Territorialforsvar og internasjonal innsats 1990-2015 (Oslo: Spartacus/SAP, 2016).

\section{Litteratur}

de Carvalho, Benjamin \& Iver B. Neumann (2015) Small State Status Seeking: Norway's Quest for International Standing. Milton Park: Routledge.

Eggen, Øyvind, Halvard Leira \& Katrine Ziesler (2015) «Ekspertkilde Eller Politiker? Medias bidrag til underskudd på utenrikspolitisk debatt», Norsk Medietidsskrift 22 (2): 1-17.

Græger, Nina (2016) Norsk forsvarspolitikk. Territorialforsvar og internasjonal innsats 1990-2015. Oslo: Spartacus/ Scandinavian Academic Press, ISBN: 978-82-304-0124-8.78

Græger, Nina (2010) «Utenriksministerens norske 'konkurrenter' - Utenriksdepartementets 'funksjonstap' på hjemmebane", Internasjonal Politikk 68(1):131-137 (Fokus: Norges utenriksministre 1987-2010).

Græger, Nina (2009) «Idealer og interesser i nytt samspill», i Kommentarer til Stortingsmeldingen 'Interesser, ansvar og muligheter: Hovedlinjer i norsk utenrikspolitikk' [j. St meld 15 (2008-2009)], Internasjonal Politikk 67(3): 517-537.

Græger, Nina (2007) «Norges globale og regionale utfordringer i utenriks- og sikkerhetspolitikken», Globale Norge - hva nå? Oslo: Utenriksdepartementet, Refleksprosjektet (on-line 6 Desember)

Græger, Nina \& Iver B. Neumann (2006) «Utenriksdepartementet og Forsvarsdepartementets rolle», s. 67-88 i Birgitte Kjos-Fonn; Ole Jakob Sending \& Iver B. Neumann (red.) Norsk utenrikspolitisk praksis. Aktorer og prosesser. Oslo: Cappelen Akademisk forlag.

Græger, Nina \& Wrenn Y. Lindgren (2017) «The Duty of Care for Citizens Abroad: Security and Responsibility in the In Amenas and Fukushima Crises", The Hague fournal of Diplomacy 12(1): 1-23, DOI: $10.1163 / 1871191 \mathrm{X}-11302009$

Haugevik, Kristin M. (2017) «Hva betyr brexit for utenforlandet Norge?», Internasjonal Politikk, 75: 152-166. http://dx.doi.org/10.23865/intpol.v75.945

Knutsen, Torbjørn L., Halvard Leira \& Iver B. Neumann (2016) Norsk utenrikspolitisk idehistorie. Oslo: Universitetsforlaget.

Leira, Halvard (2005) «Folket og freden. Utviklingstrekk i norsk fredsdiskurs 1890-2005», Internasjonal Politikk 63(2): 135-160.

Leira, Halvard (red.) (2007) Norske selvbilder og norsk utenrikspolitikk. Oslo: NUPI.

Leira, Halvard (2012) «Drømmen Om en Ny Utenrikspolitikk.», Nytt Norsk Tidsskrift 29(4): 383-94.

Leira, Halvard (2013) «Innledning: Arven Etter Støre», Internasjonal Politikk 71(3): 371-81.

Leira, Halvard (2017) «Caring and Carers: Diplomatic Personnel and the Duty of Care», The Hague fournal of Diplomacy. doi 10.1163/1871191X-11302007

Leira, Halvard, \& Ulf Sverdrup (2013) «Norske Utenrikspolitiske Interesser - Endringer i Praksis, Stillstand i Debatt.» Nytt Norsk Tidsskrift 30(4): 337-48.

Leira, Halvard \& Ulf Sverdrup (2015) «Norske Interesser Og Norske Utestasjoner.» Oslo: NUPI.

Narud, Hanne Marthe, Helge Hveem \& Bjørn Høyland (2010) «Gamle konflikter - nye saker? Norske velgeres utenriks- og sikkerhetspolitiske holdninger", Internasjonal Politikk 68(3): 334-363.

Neumann, Iver B. (2010). «Utenriksministerens Spillerom, 1972-2010.» Internasjonal Politikk 68 (1): 115-30.

Neumann, Iver B. \& Halvard Leira (2005) Aktiv og avventende i hundre år. Utenrikstjenestens liv 1905-2005. Oslo: Pax.

Romarheim, Anders G. (2017) «USA og Norge i Trumps verden», Internasjonal Politikk, 75(1): 1-9. http:// dx.doi.org/10.23865/ip.v75.696

Stortingsmelding nr. 15 (2008-2009) Interesser, ansvar og muligheter. Hovedlinjer $i$ norsk utenrikspolitikk. Oslo: Utenriksdepartementet

Sverdrup-Thygeson, Bjørnar (2016) «Forbrytelse og straff» Forholdet mellom Norge og Kina», Internasjonal Politikk, 74(3): 1-12.

Udgaard, Nils Morten (2006) «Statsministerens kontor - minst men mektigst?» s. 48-66 i Birgitte Kjos Fonn, Iver B. Neumann \& Ole Jacob Sending (red.) Norsk utenrikspolitisk praksis. Aktører og prosesser. Oslo: Cappelen. 